\title{
POLLEN MORPHOLOGY OF PLANTAGO SPECIES NATIVE TO POLAND AND THEIR TAXONOMIC IMPLICATIONS
}

\author{
MAŁGORZATA KLIMKO ${ }^{1}$, KRYSTYNA IDZIKOWSKA ${ }^{2}$, \\ MARIOLA TRUCHAN ${ }^{3}$, ANNA KREFT ${ }^{3}$ \\ ${ }^{1}$ Department of Botany, Agricultural University \\ Wojska Polskiego 71C, 60-625 Poznań, Poland \\ e-mail: klim@owl.au.poznan.pl \\ ${ }^{2}$ Laboratory of Electron Microscopy, Adam Mickiewicz University \\ Grunwaldzka 6, 70-780 Poznań, Poland \\ ${ }^{3}$ Department of Botany and Genetics, Institute of Biology and Environmental Protection, \\ Pomeranian Pedagogical University \\ Arciszewskiego 22B, 76-200 Słupsk, Poland
}

(Received: March 29, 2004. Accepted: May 21, 2004)

\begin{abstract}
Pollen grains of 9 species of the genus Plantago (Plantaginaceae), including 8 taxa native to Poland, were observed under a light microscope and a scanning electron microscope. Descriptions of grain sculpture are illustrated only SEM micrographs. The studied pollen grains were medium-sized or small, spherical or prolate spheroidal. Their sculpture was always verrucate with granulation. In the studied taxa, internal apertures had the form of pores. Their number ranged from (4)5-9(14). The pores were scattered on the surface of pollen grains. Identification features of individual taxa include: presence or absence of an annulus around each pore, annulus structure, ornamentation of the pollen grain and operculum, type of aperture membrane, number of internal pores, and pore diameter. We suggest that two new pollen grain types, characteristic of $P$. intermedia and $P$. arenaria, should be distinguished, and that $P$. alpina should be assigned to the $P$. coronopus type.
\end{abstract}

KEY WORDS: Plantaginaceae, Plantago, pollen morphology, SEM.

\section{INTRODUCTION}

Pollen grains of the genus Plantago (Plantaginaceae) have been subject to scientific research for many years, mainly in the field of paleobotany, because species like $P$. $m a$ jor, $P$. media and $P$. lanceolata are regarded as indicators of human settlements in prehistoric investigations.

Generative parts of plants, mature pollen grains in particular, are much less variable than vegetative parts. Hence, pollen is a convenient material for investigation, because it is in a steady physiological stage, has a single set of chromosomes, and forms large populations. Mature pollen grain size, exine sculpturing, and number of pores are the most distinctive features (Erdtman 1952; Fægri and Iversen 1992; Klimko et al. 2000). The ontogenesis of pollen involves important genetic control phenomena, such as the connection between meiocytes, callose synthesis for the separation of microspores, tapetal secretion, which is deposited as components of pollen coat, and finally the determination of exine patterns. The exine pattern is controlled by the sporophyte, whereas pollen size is determined both by sporophytic and gametophytic genotypes (Bedinger 1992; McCormic 1993; Nepi et al. 1995; Ottaviano and Mulcahy 1989; Stanley and Linskens 1975; and references therein). It is unknown how the specific pollen wall patterns are determined, but the sculpturing is exclusively under sporophytic control and no segregation of the exine pattern is known (Heslop-Harrison 1971, 1972).

As a result of palynological studies, pollen grains of the genus Plantago have been divided into several types. Iversen (1941) distinguished two types: lanceolata and majormedia. Müller (1943) added a third type, coronopus, and Casper (1975) another one, maritima. Taxonomic reviews of pollen morphology based on modern materials distinguish pollen grain types characteristic of individual taxa or else group several species in one type (Casper 1975; Clarke, Jones 1977). However, the materials came mainly from NW Europe. In Poland such investigations have not been conducted so far. Despite intensive research, there are still some discrepancies in classification, morphological de- 
scriptions of annuli of pores, ornamentation of pollen grains, shape and size of verrucae, type of granulation, pore diameter, and ornamentation of the membrane closing the pores. Most papers present results of observations made under a light microscope (Straka in Casper 1975; Fægry, Iversen 1975; Moore et al. 1991; Sadowska et al. 1986; Stachurska et al. 1981) and only few under a scanning electron microscope (Clarke, Jones 1977). Hence the aim of our study was to assess the variation of qualitative and quantitative traits of pollen grains in population material and to perform a statistical analysis of similarity between the distinguished types of pollen grains, corresponding to strictly defined species.

The Polish flora includes ten Plantago species, including three threatened taxa (Polish Red Data Book of plants 2001). P. coronopus L. is critically endangered in Poland, as it has been found in only one natural locality: Karsibór in the SE part of Usedom Island (Piotrowska 2001). P. maritima L. subsp. maritima is also endangered (Piotrowska 2001), while $P$. atrata Hoppe subsp. carpatica (Soó) Soó (= var. carpathica Pilger) is endemic to the Carpathians (Piękoś-Mirkowa 2001). We have not managed to acquire material of $P$. winteri (Tacik 1967; Rutkowski 1998).

\section{MATERIAL AND METHODS}

The population material for pollen analysis was collected from many man-made habitats. Only pollen of $P$. atrata subsp. carpatica originated from herbarium materials of POZB and the Experimental Garden of the Polish Academy of Sciences, while $P$. maritima subsp. maritima and $P$. coronopus subsp. coronopus from natural habitats. Pollen grains were extracted from ripe anthers.

List of localities (Fig. 1):

$P$. major L.

1. Pomerania, Słupsk Commune - roadsides

2. Wielkopolska, Poznań Commune - roadsides
3. Wielkopolska, Nowy Tomyśl Commune - paths

4. Wielkopolska, Mosina Commune - near buildings

5. Wielkopolska, Puszczykowo Commune - near buildings

P. intermedia Gilib.

6. Pomerania, Rowy, Ustka Commune - edges of lakes

7. Pomerania, Karlino Commune - cultivated fields

8. Pomerania, Parsęcko, Szczecinek Commune - cultivated fields

9. Wielkopolska, Stęszew Commune - edges of lakes

10. Wielkopolska, Niwka, Puszczykowo Commune - edges of ponds

$P$. media L.

11. Pomerania, Tczew Commune - slopes of a pond

12. Pomerania, Pyrzyce Commune - meadow

13. Wielkopolska, Puszczykowo Commune - roadside ditch

14. Wielkopolska, Skorzęcin, Witkowo Commune - meadow

15. Wielkopolska, Konin Commune - roadside ditch

16. Mazovia, Warszawa Commune - slopes of a pond

P. coronopus L. subsp. coronopus

17. Pomerania, SE of Usedom Island, Karsibór, Brzeźno Commune - halophilic meadow

$P$. maritima L. subsp. maritima

18. Pomerania, Władysławowo Commune - halophilic meadow

P. atrata Hoppe subsp. carpatica (Soó) Soó

19. Małopolska, Zakopane Commune - Experimental Garden, fresh and herbarium material (POZB) from Szalony Wierch

P. lanceolata $\mathrm{L}$.

20. Pomerania, Przechlewo Commune - meadow

21. Pomerania, Kluki, Smołdzino Commune - meadow

22. Wielkopolska, Mosina Commune - roadside

23. Wielkopolska, Nowy Tomyśl Commune - roadside

24. Wielkopolska, Poznań Commune - roadside

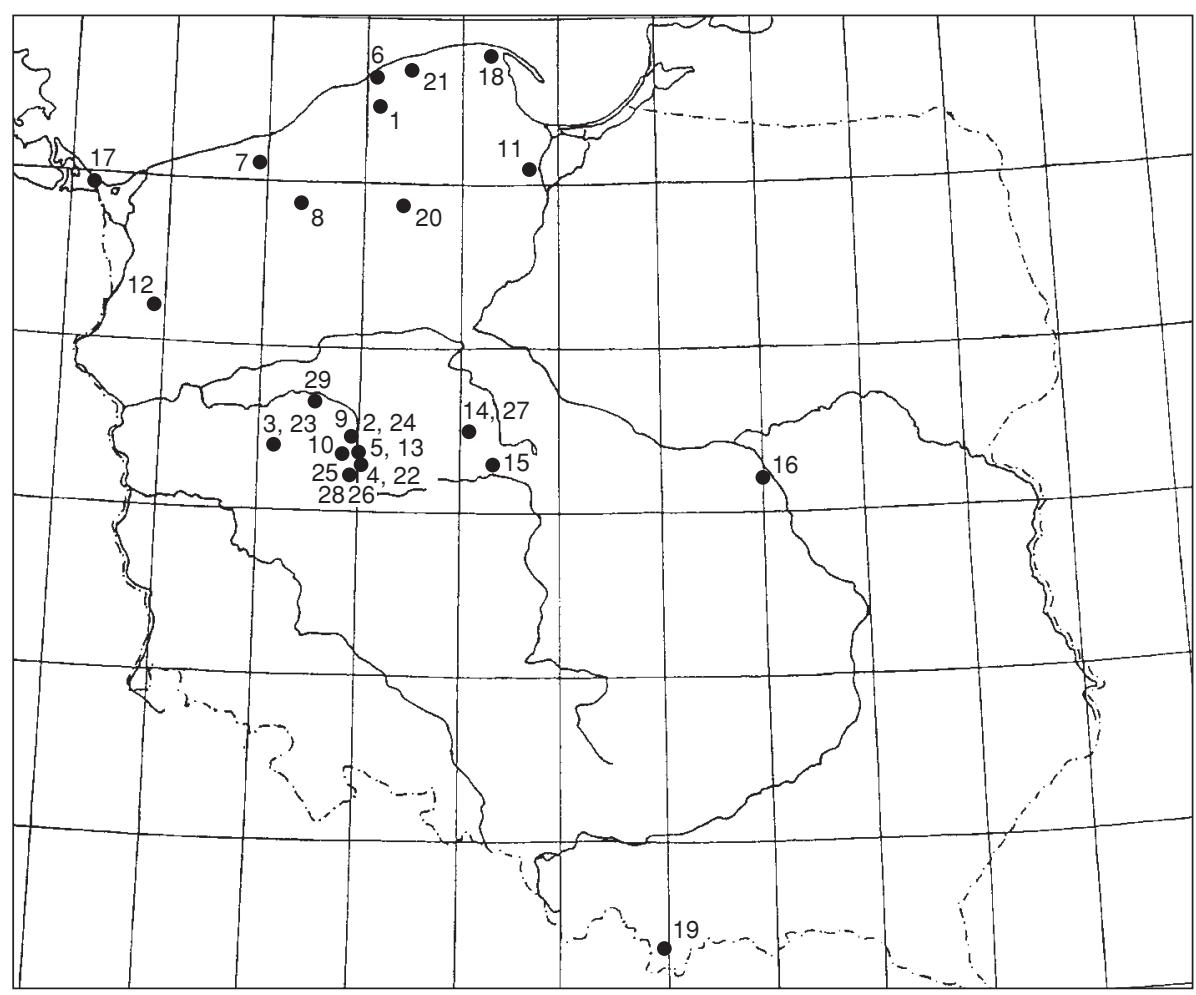

Fig. 1. List of localities. 


\section{P. arenaria Waldst. \& Kit.}

25. Wielkopolska, Puszczykówko, Puszczykowo Commune - sandy patch surrounded by forest

26. Wielkopolska, Rogalinek, Mosina Commune - sandy patch surrounded by forest

27. Wielkopolska, Skorzęcin, Witkowo Commune - sandy patch surrounded by forest

28. Wielkopolska, Szreniawa, Komorniki Commune sandy patch surrounded by forest
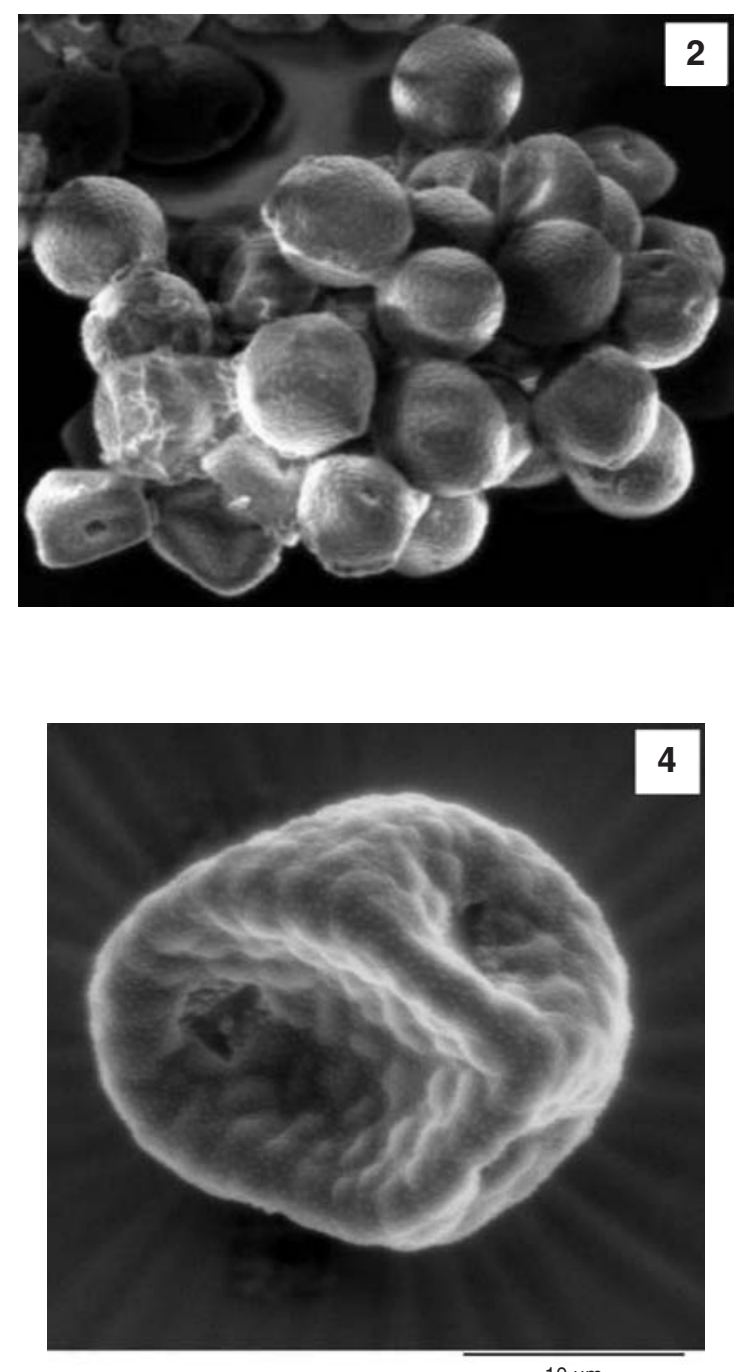

$10 \mu \mathrm{m}$

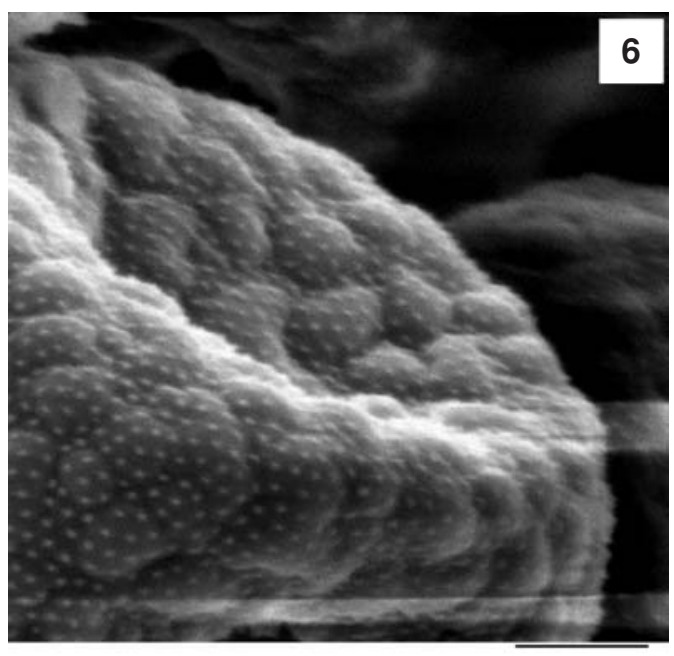

$30 \mu \mathrm{m}$
29. Wielkopolska, Obrzycko Commune - sandy patch surrounded by forest

Additionally, we analysed a sample of pollen of $P$. alpi$n a \mathrm{~L}$. for comparison with $P$. maritima, because of its earlier classification (Clarke, Jones 1977).

Pollen grain dimensions were measured in the equatorial (E) and polar (P) plane by means of Lucia 3.5 software (Laboratory Imaging Ltd., Czech Republic) on a computer linked with a microscope. The measurements were taken
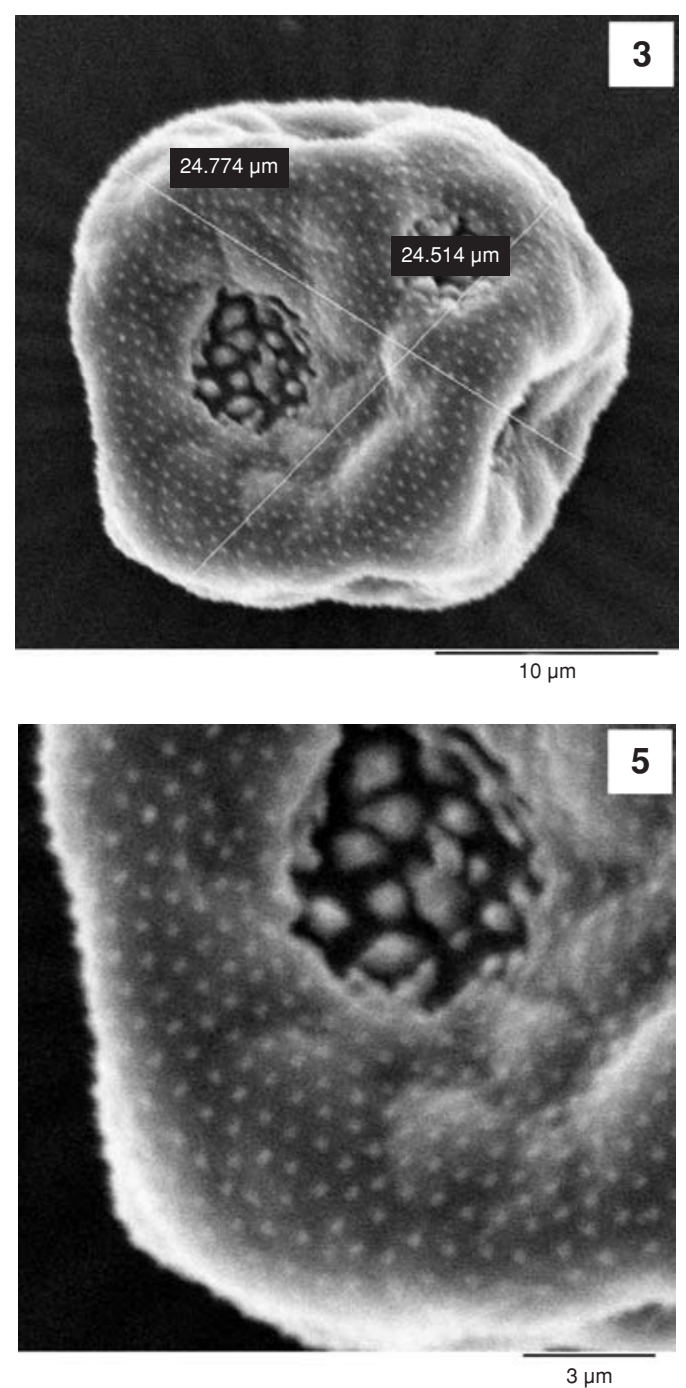

Figs 2-6. Plantago major $\mathrm{L}$.

Fig. 2. Pollen grains $(\times 600)$.

Fig. 3. Overall view with pores $(\times 3100)$.

Fig. 4. Overall view with verrucae $(\times 3100)$.

Fig. 5. Pore and granulate operculum $(\times 6200)$.

Fig. 6. Verrucae $(\times 6200)$. 
for 30 pollen grains from each locality of each species. A total of 900 pollen grains were measured. We calculated mean values. On the basis of the results, the studied samples were assigned to microspore size classes. The ratio of length in the $\mathrm{P}$ plane to that in the $\mathrm{E}$ plane enabled an assessment of microspore shape, which was classified according to Erdtman (1952). We also measured pore diameter and annulus width. Moreover, qualitative traits concerning the stage of development of the annulus, operculum, aperture membrane, and verruca structure, were taken into account. Values of those traits are given below:

- annulus continuous, well-developed -3 ,

- annulus partly open -2 ,

- annulus composed of disjunct verrucae -1 ,

- no annulus -0 ,

- operculum solid - 2,

- aperture membrane granulate -1 ,

- verrucae well-developed, prominent - 3,

- verrucae clearly convex -2 ,

- verrucae slightly convex -1 .

In this study we did not perform acetolysis because it causes swelling of pollen grains and damages the operculum (Clarke, Jones 1977).

A series of 90 of comparative micrographs of the studied species were taken under a scanning electron microscope (Phillips FEN 515) in order to assess the sculpture and apertures of pollen grains. The micrographs were taken in the Electron Microscopy Unit, Adam Mickiewicz University, Poznań. Mutual relationships and differences between species were presented on the basis of the clustering method described by Sokal and Sneath (1963). The fenogram was constructed by the cluster analysis module of Statistica Software (StatSoft 2002).

Nomenclature follows that recommended by Mirek et al. (1995).

\section{RESULTS AND DISCUSSION}

Mature pollen grains of Plantago species are medium-sized or small, spherical or prolate spheroidal, always verrucate (verrucae varying in size and shape), with granulation.

The annulus in the Plantaginaceae seems to be formed by a thickening and aggregation of verrucae around the pores. In some species the annulus is continuous, but in other cases the verrucae are disjunct and form a partial annulus. The operculum in some species is a solid lid whose structure seems to be identical with the rest of sexine. Other species have a partial operculum, with sexine granules on the aperture membrane. These granules are usually widely spaced and small, but may be larger. Exine is rather thin or moderately thick, sexine undulating, about twice as thick as nexine (Clarke, Jones 1977).

\section{Species: Plantago major L.}

\section{Plantago major type (Figs 2-6)}

Pollen class: (4)5-9 pantoporate.

Size: medium, P - 21.76 $\mu \mathrm{m}(17.79-28.47 \mu \mathrm{m}), \mathrm{E}-18.51$ $\mu \mathrm{m}(14.81-24.51 \mu \mathrm{m})$.

P/E ratio: 1.04 (1.00-1.16), grains usually prolate spheroidal, sometimes spherical or subprolate.

Apertures: Ectoaperture - pore, rather irregular to \pm circu- lar, stronglysunken, diameter $4.59 \mu \mathrm{m}(2.31-5.42 \mu \mathrm{m})$, margin ill-defined, irregular, annulus absent; aperture membrane covered with granules forming an ill-defined operculum. Endoaperture - pore congruent with ectoaperture, formed by a thin area of nexine.

Ornamentation: Verrucate, the verrucae well-defined, medium-sized, slightly convex, irregular in outline. Their size varies around the pore. Channels between verrucae with distinct granules.

Comments: Fægri, Iversen (1992) reported that the pores are ill-defined, without operculum. By contrast, Clarke, Jones (1977) described the verrucae in $P$. major as well-defined but smaller than in many other species, and our results confirm this. The size of verrucae is similar to that in $P$. media, but they are less convex. Disparities in published data concern also pore diameter. According to Dietrich (1968), it is equal to $3 \mu \mathrm{m}$, while according to Clarke, Jones (lc) it ranges from 3 to $5 \mu \mathrm{m}$. In our study, pore diameter varied from $2.31 \mu \mathrm{m}$ to $5.42 \mu \mathrm{m}$.

\section{Species: Plantago intermedia Gilib. Plantago intermedia type (Figs 7-9) \\ Pollen class: (4)5-9 pantoporate.}

Size: medium, P - $23.25 \mu \mathrm{m}(19.58-27.20 \mu \mathrm{m}), \mathrm{E}-19.56$ $\mu \mathrm{m}(16.30-23.15 \mu \mathrm{m})$, sometimes small-sized (see Comments)

P/E ratio: 1.18 (1.17-1.20): grains usually subprolate.

Apertures: Ectoaperture - pore irregular to \pm elliptical in outline, often clearly sunken, diameter $2.37 \mu \mathrm{m}(1.33-2.78$ $\mu \mathrm{m})$, margin ill- or well-defined, annulus absent; membrane covered with sexine granules forming an ill-defined operculum. Endoaperture - pore congruent with ectoaperture, formed by a thin area of nexine.

Ornamentation: Verrucate, the verrucae very well-defined, varying in size and shape, small or large, club-shaped. Channels between verrucae with distinct but fine granulation.

Comments: Pollen grains of $P$. intermedia in ripe anthers varied in size to a large extent. Apart from those described above, some grains were small-sized: $\mathrm{P}-5.52 \mu \mathrm{m}(2.95$ $-7.60 \mu \mathrm{m}), \mathrm{E}-5.02 \mu \mathrm{m}(2.11-7.18 \mu \mathrm{m}), \mathrm{P} / \mathrm{E}$ ratio: 1.21 (0.66-1.66). Pore diameter $0.70 \mu \mathrm{m}(0.67-0.72 \mu \mathrm{m})$. In earlier studies, $P$. intermedia was not considered a species, as the nomenclature and selection of species followed Chater and Cartier (1976). Clarke and Jones (1977) report that they detected no difference in pollen morphology between the two subspecies of $P$. major (ssp. major and ssp. intermedia). Our results attest to marked differences in pollen grain sculpture, shape, pore diameter, and size between $P$. major and $P$. intermedia. The differences in pollen grain traits and seed sculpture (Klimko et al. 2004), fully justify the separation of $P$. intermedia as a distinct species.

\section{Species: Plantago media $\mathbf{L}$.}

Plantago media type (Figs 10-13)

Pollen class: 4-8 pantoporate.

Size: medium, $\mathrm{P}-27.48 \mu \mathrm{m}(22.86-32.76 \mu \mathrm{m}), \mathrm{E}-25.72$ $\mu \mathrm{m}(21.05-29.79 \mu \mathrm{m})$.

P/E ratio: 1.06 (1.00-1.13): grains usually prolate spheroidal or spherical.

Apertures: Ectoaperture - pore rather irregular to \pm circular in outline, often sunken, pore diameter $4.08 \mu \mathrm{m}$ (3.50-5.12 $\mu \mathrm{m})$; margin ill-defined, annulus absent; membrane cove- 

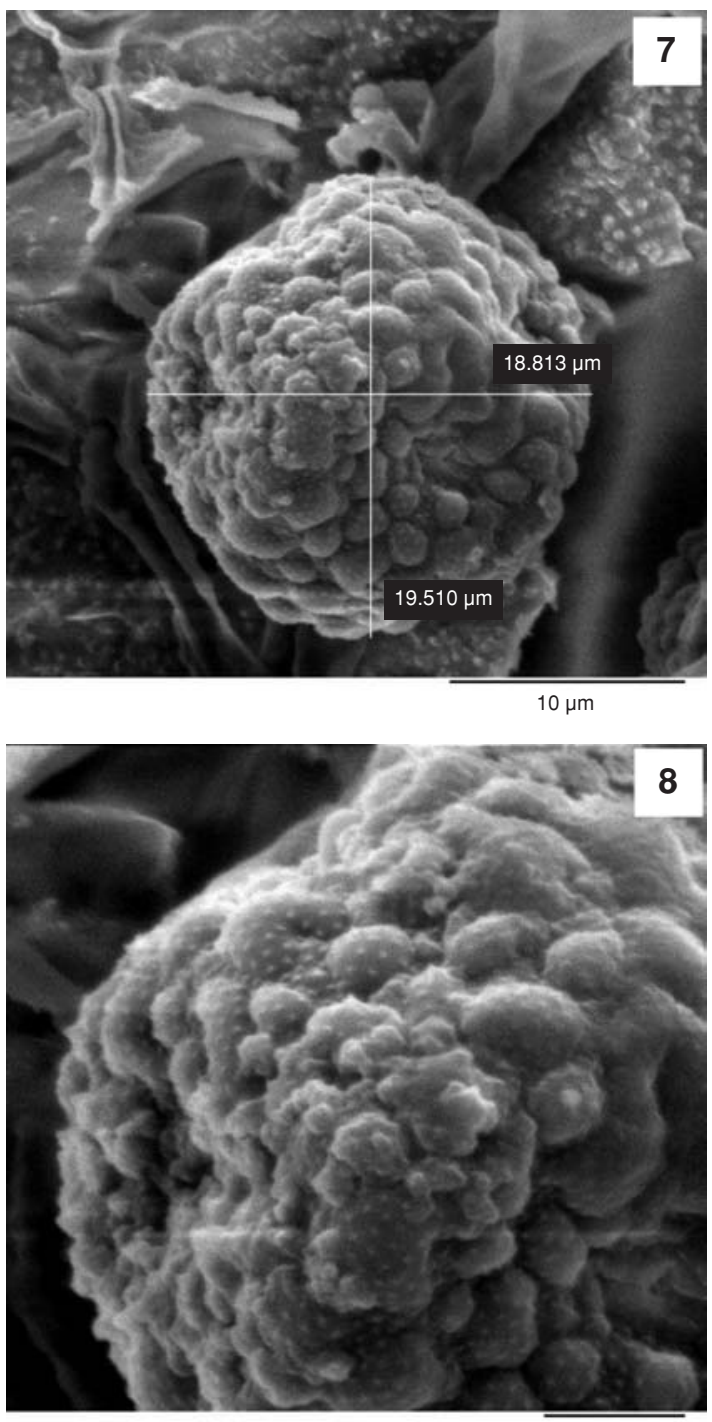

$3 \mu \mathrm{m}$

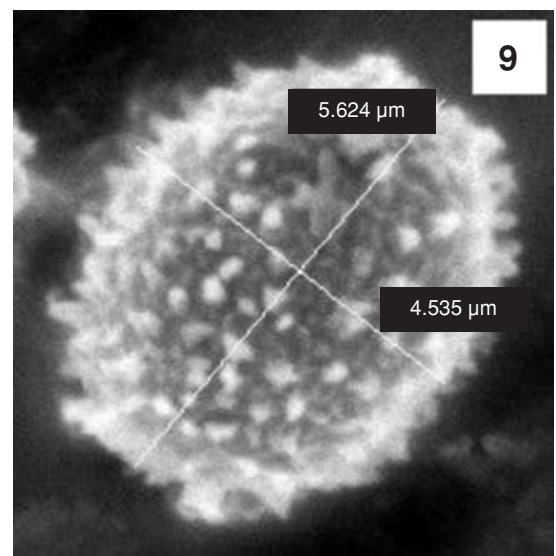

Figs 7-9. Plantago intermedia Gilib.

Fig. 7. Overall view $(\times 3100)$.

Fig. 8. Verrucae and pore $(\times 6200)$.

Fig. 9. Overall view $(\times 6200)$.

red with sexine granules forming an ill-defined operculum. Endoaperture - pore congruent with ectoaperture.

Ornamentation: Verrucate, the verrucae large, coarse, we11-defined, irregular in outline, not concentrated or differentiated around pores. Channels between verrucae with minute puncta.
Comments: The verrucae of $P$. media type are large, denser and very coarse. Sculpture more rough and conspicuous than in any other pollen type in the family. Our results confirmed the data on pore diameter given by Clarke, Jones (1977) and Fægri, Iversen (1992). An earlier study (Czapska 1959) showed that morphologically different specimens of $P$. media from different habitats do not vary in pollen grain diameter.

\section{Species: Plantago coronopus subsp. coronopus} Plantago coronopus type (Figs 14-16)

Pollen class: (4)5-8 (9) pantoporate.

Size: medium, P - 27.57 um (24.20-30.44 um), E - 22.90 $\mu \mathrm{m}(19.69-24.94 \mu \mathrm{m})$.

P/E ratio: 1.20 (1.04-1.22): grains usually spherical or prolate spheroidal

Apertures: Ectoaperture - pore \pm circular in outline, pore diameter $2.02 \mu \mathrm{m}(1.54-2.13 \mu \mathrm{m})$; margin well-defined, regular, with a wide, continuous, raised annulus 2.68 $\mu \mathrm{m}(1.80-3.27 \mu \mathrm{m})$, membrane covered with irregular sexine granules, forming an ill-defined operculum. Endoaperture - pore congruent with ectoaperture, formed by a thin area of nexine.

Ornamentation: Verrucate, the verrucae large, well-defined, irregular to \pm circular in outline; channels between verrucae with very few puncta.

Comments: The distinguishing character of the $P$. coronopus type is the very prominent annulus, which is better developed than in any other species in Poland and NW Europe (Clarke, Jones 1997). Pore diameter in our materials from Poland (mean $2.68 \mu \mathrm{m}$ ) was lower than in NW Europe $(3-4 \mu \mathrm{m})$.

\section{Species Plantago alpina $\mathrm{L}$.}

\section{Plantago coronopus type (Figs 17-19)}

Pollen class: 6-8 pantoporate.

Size: medium, P - 25.37 um (23.68-26.05 um), E - 24.13 $\mu \mathrm{m}(22.89-25.26 \mu \mathrm{m})$.

P/E ratio: 1.04 (1.00-1.14): grains usually prolate spheroidal or spherical.

Apertures: Ectoaperture - pore \pm circular or elliptical in outline; diameter $2.56 \mu \mathrm{m}$, margin well-defined. Annulus present, $1.20 \mu \mathrm{m}$ wide, partly open, aperture membrane convex, not granulate (Fig. 18), but small, prominent, microechinae granulation is visible on operculum edges, operculum very well-defined. Endoaperture - pore congruent with ectoaperture.

Ornamentation: Verrucate, the verrucae medium-sized, slightly convex, irregular in outline; around pores, the verrucae long, prominent; channels between verrucae with puncta.

Comments: Clarke, Jones (1977) pollen of $P$. alpina is assigned to the maritima type because of similarities in annulus structure. In $P$. maritima the annulus is discontinuous, composed of single verrucae, while in $P$. alpina it consists of one small and two larger, elongated, verrucae. Some differences concern also operculum structure (see Figs 18, 22). The mean size of grains is consistent with data from Müller (1947). That author assigned pollen of $P$. alpina to the coronopus type, which is right in our opinion. 

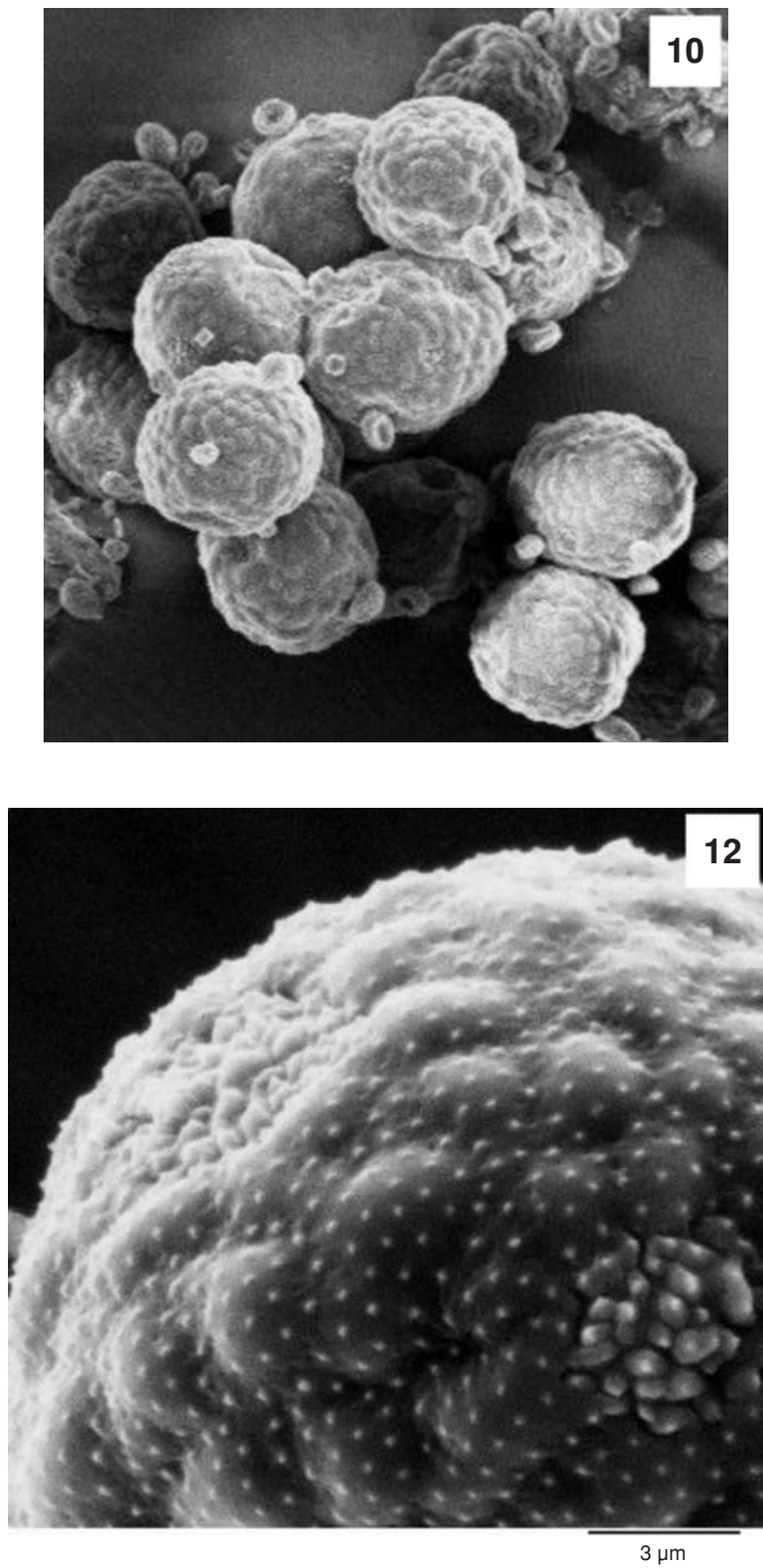

Figs 10-13. Plantago media $\mathrm{L}$.

Fig. 10. Pollen grains $(\times 600)$.

Fig. 11. Overall view with pore $(\times 3100)$.

Fig. 12. Pore with granulate operculum $(\times 6200)$

Fig. 13. Pores with granulate opercula $(\times 2020)$.

\section{Species Plantago maritima L. subsp. maritima}

Plantago maritima type (Figs 20-22)

Pollen class: 5-8 (9) pantoporate.

Size: medium, $\mathrm{P}-23.41 \mu \mathrm{m}(18.76-27.06 \mu \mathrm{m}), \mathrm{E}-19.38$ um (16.32-20.93 um).

P/E ratio: 1.19 (1.14-1.21): grains usually prolate spheroidal or subprolate.

Apertures: Ectoaperture - pore \pm circular in outline, diameter 3.85 um (2.45-3.62 $\mu \mathrm{m})$; margin clearly defined, annulus absent or weak, formed by a series of verrucae surrounding the pore, membrane covered with sexine granules and an outgrowth forming an ill-defined operculum. Endoaperture - pore congruent with ectoaperture, formed by a thin area of nexine.
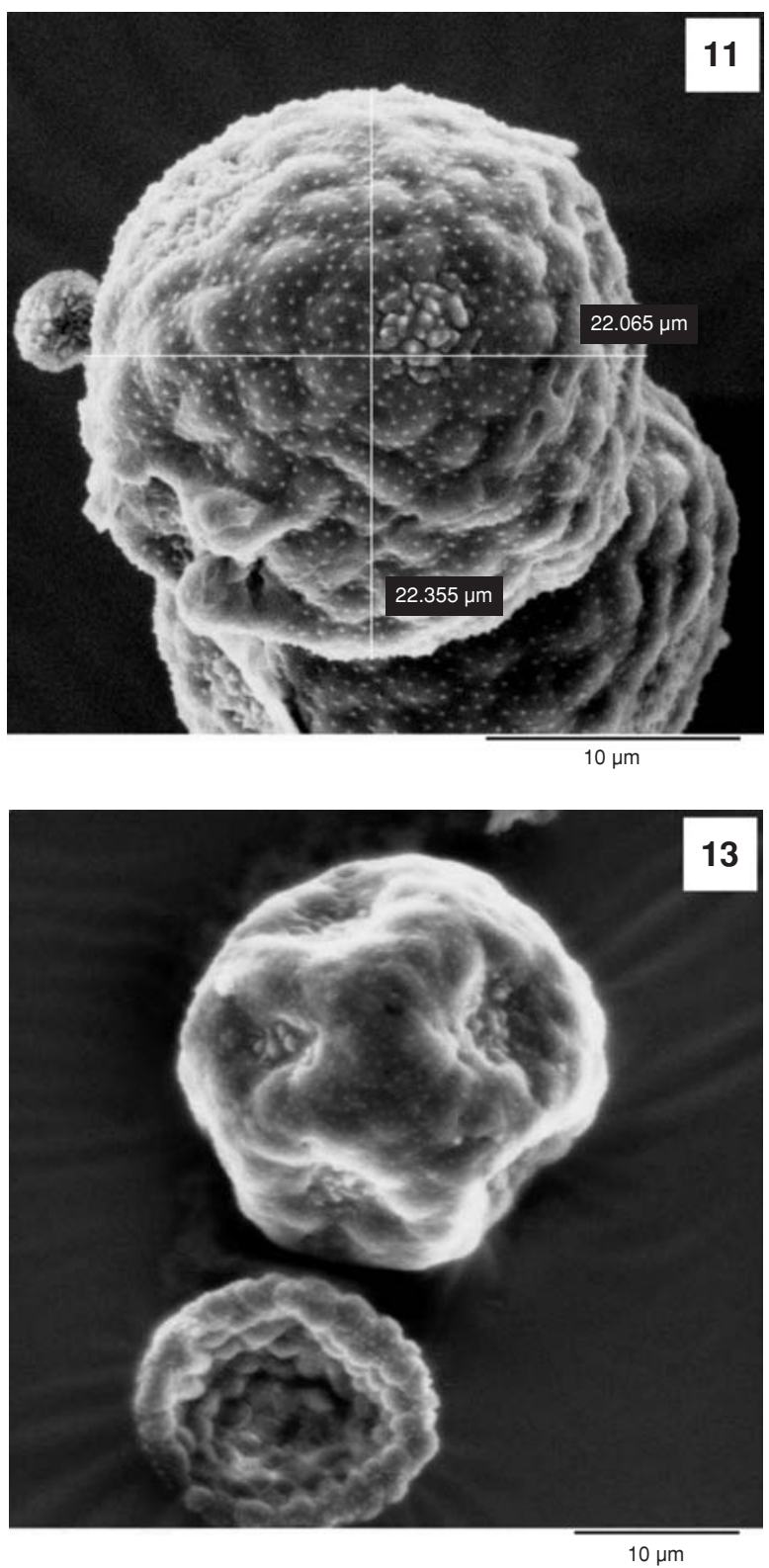

Ornamentation: Verrucate, the verrucae well-defined, \pm circular in outline; verrucae surrounding the pore slightly to distinctly denser; channels between verrucae with distinct granula.

Comments: Fægri, Iversen (1992) and More et al. (1991) report that pollen grains of this species lack opercula and are distinctly microechinae. Pore diameter 3-5 mm. Material from Poland was characterized by smaller pores and uniform annulus structure, composed of disjunct verrucae. As reported by Clarke and Jones (lc), the $P$. maritima type is morphologically the most variable type of the family in NW Europe. $P$. arenaria and $P$. alpina are assigned to this type. The species included in this type are taxonomically distinct: $P$. maritima and $P$. alpina belong to the section Maritima, while $P$. arenaria to the section Psyllium. 

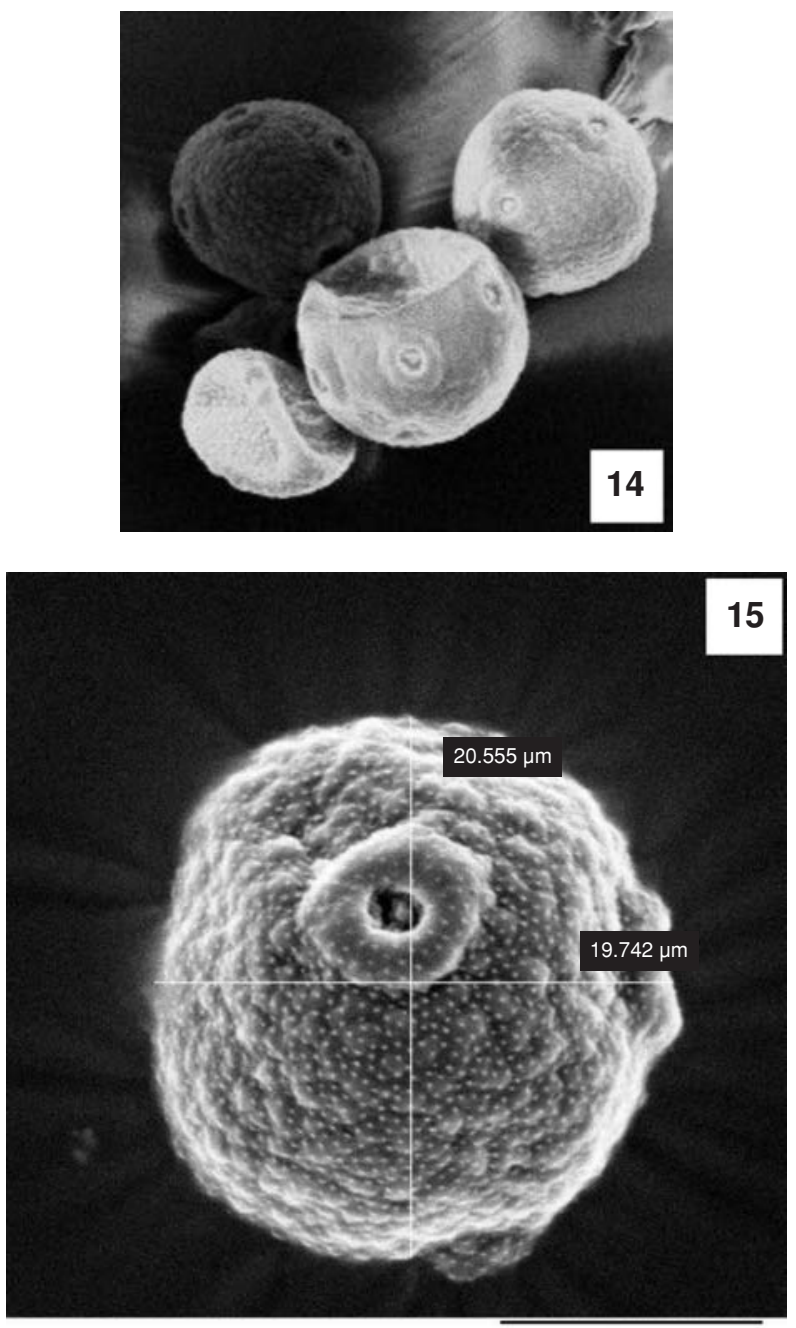

$10 \mu \mathrm{m}$

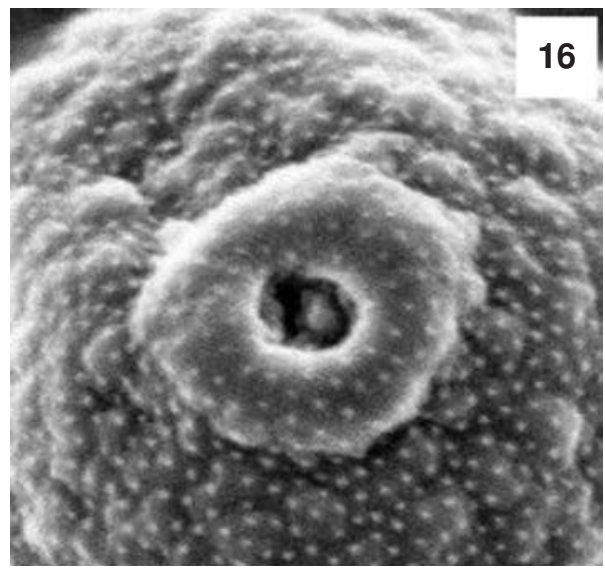

Figs 14-16. Plantago coronopus L. subsp. coronopus.

Fig. 14. Pollen grains $(\times 600)$.

Fig. 15. Overall view with pore and annulus $(\times 3100)$.

Fig. 16. Annulus $(\times 3100)$

Species Plantago atrata Hoppe subsp. carpatica (syn. P. montana Lam.)

Plantago atrata type (Figs 23-25)

Pollen class: 4-6 pantoporate.

Size: medium, P - 29.65 um (27.12-31.58 um), E - 25.76 um $(23.68-28.42 \mu \mathrm{m})$.

P/E ratio: 1.15 (1.01-1.25): grains usually prolate spheroidal or \pm spherical.
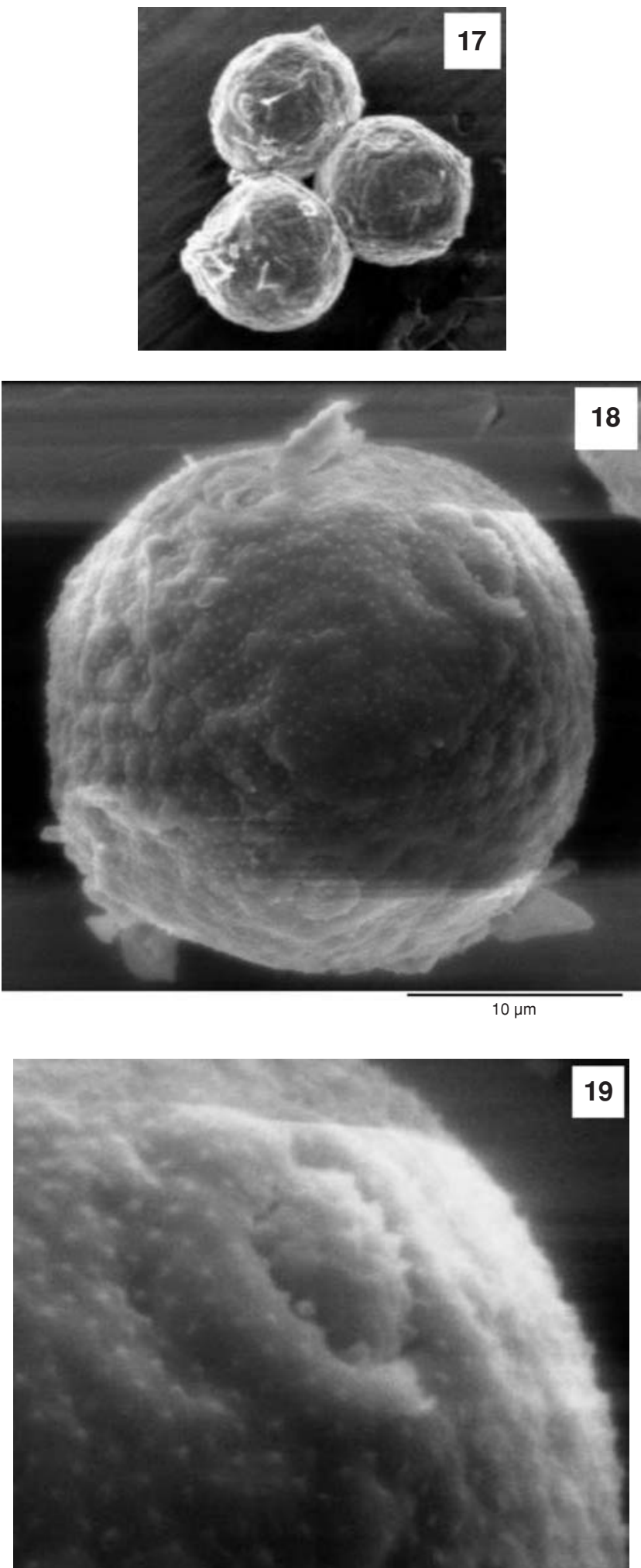

Figs 17-19. Plantago alpina $\mathrm{L}$.

Fig. 17. Pollen grains $(\times 600)$

Fig. 18. Overall view with ornamentation and pore $(\times 3100)$.

Fig. 19. Pore with annulus, detail of ornamentation $(\times 6200)$.

Apertures: Ectoaperture - pore \pm circular or irregular in outline, slightly sunken; pore diameter 3.72 $\mu \mathrm{m}$ (3.00-4.00 $\mu \mathrm{m})$, margin ill-defined, irregular; annulus absent; membrane covered with granules forming an ill-defined operculum. Endoaperture - pore congruent with ectoaperture, formed by a thin nexine. 

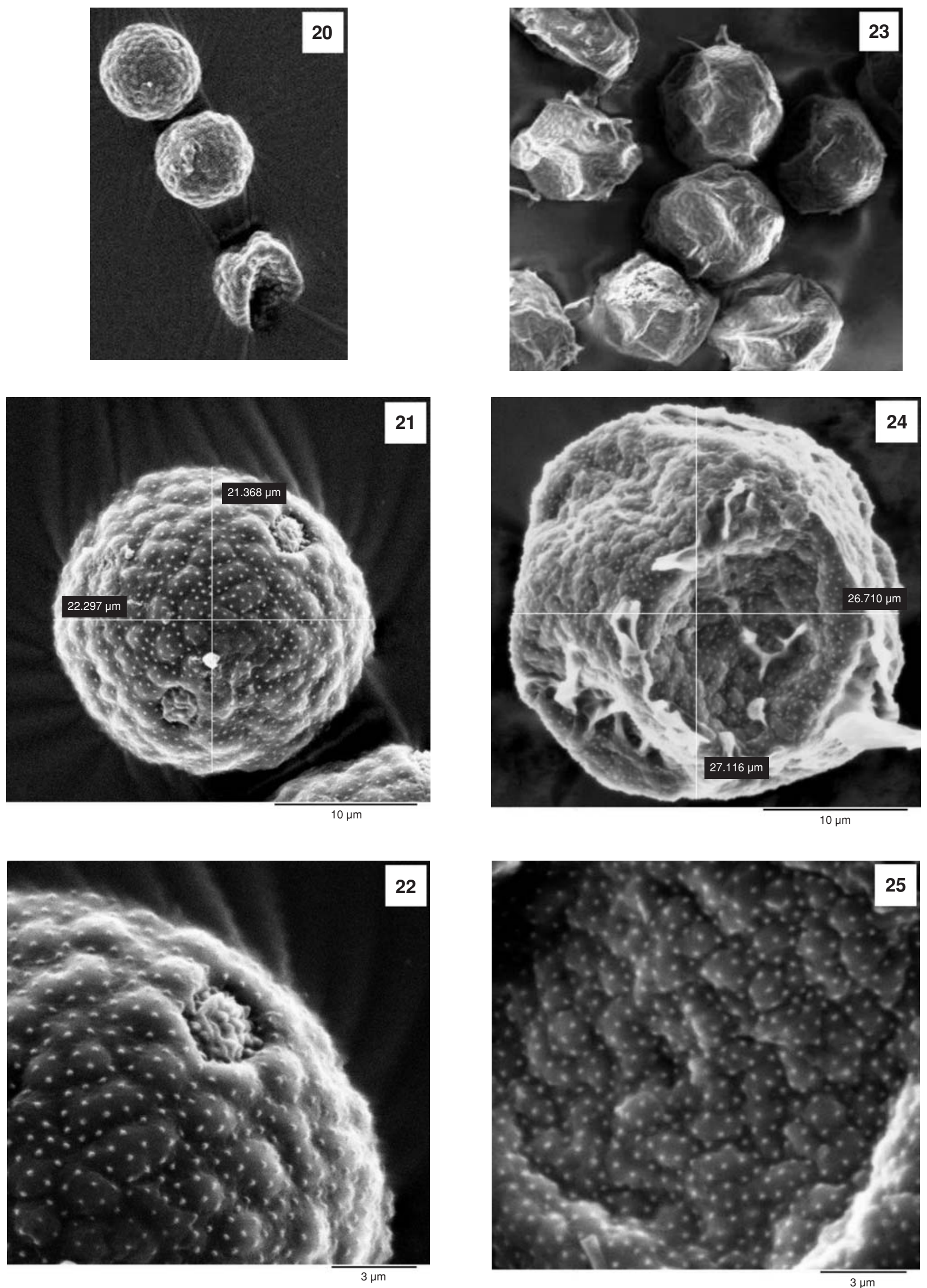

Figs 20-22. Plantago maritima L. subsp. maritima.

Fig. 20. Pollen grains $(\times 600)$

Fig. 21. Ornamentation and pores $(\times 3100)$

Fig. 22. Sculpture and pore with granulate operculum $(\times 6200)$.

Figs 23-25. Plantago atrata Hoppe subsp. carpatica (Soó) Soó.

Fig. 23. Pollen grains $(\times 600)$

Fig. 24. Overall view with ill-defined pores $(\times 3100)$.

Fig. 25. Detail of ornamentation: verrucae with puncta $(\times 6200)$. 

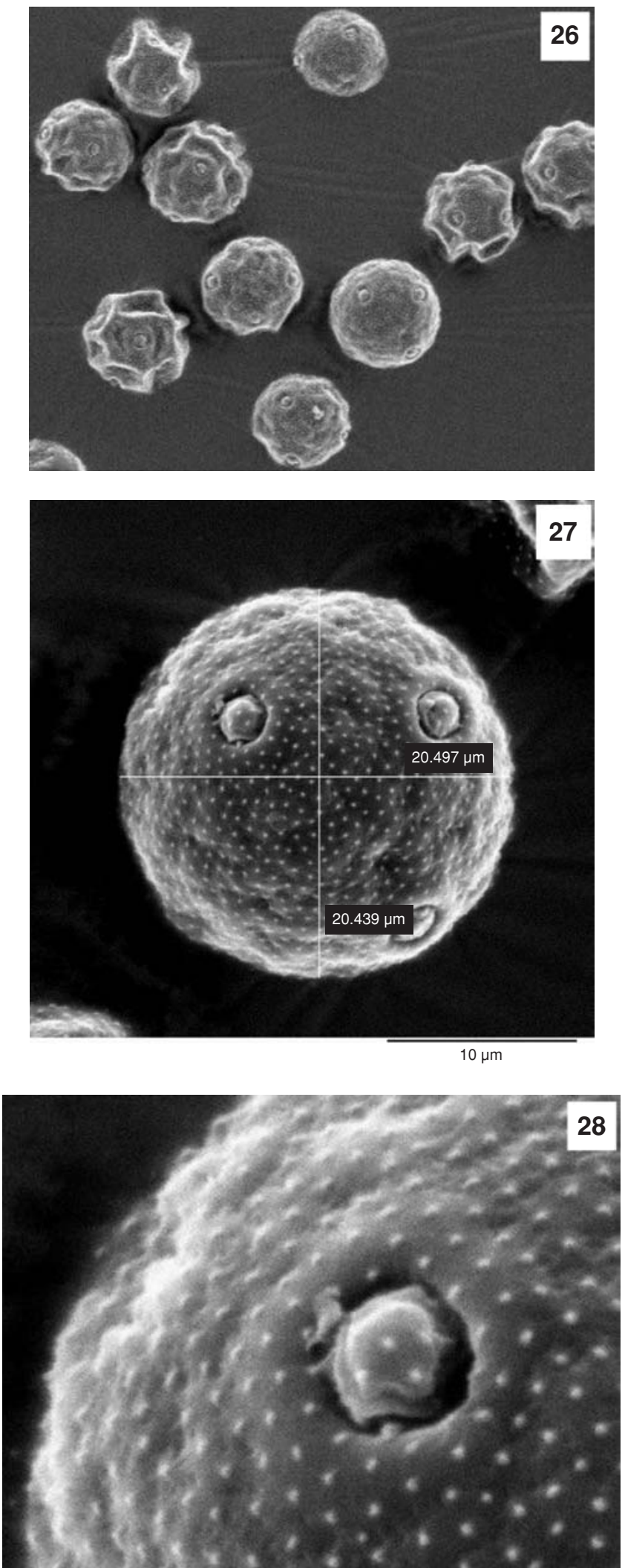

Figs 26-28. Plantago lanceolata $\mathbf{L}$.

Fig. 26. Pollen grains $(\times 600)$.

Fig. 27. Overall view with pores $(\times 3100)$.

Fig. 28. Annulus and solid operculum $(\times 6200)$.

Ornamentation: Verrucate, the verrucae very well-defined, coarse, rather flat, irregular in outline, varying in size around the pore. Channels between verrucae with distinct granule.
Comments: Pollen grains of and $P$. alpina are verrucate. In $P$. atrata subsp. carpatica the verrucae are well-defined, with marked granulation; annulus absent. By contrast, in $P$. alpina the annulus is present, although discontinuous, and operculum is well-defined. In $P$. atrata subsp. carpatica, operculum is ill-defined. Aperture membrane is not reticulate or minutely verrucate, which contrasts with the findings of Stachurska et al. (1981).

\section{Species Plantago lanceolata $\mathbf{L}$.}

Plantago lanceolata type (Figs 26-28)

Pollen class: (7)9-12 (16) pantoporate.

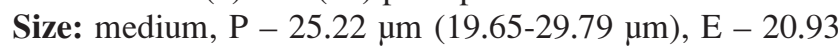
$\mu \mathrm{m}(16.58-26.16 \mu \mathrm{m})$.

P/E ratio: 1.03 (1.00-1.11): grains usually spherical or prolate spheroidal.

Apertures: Ectoaperture - pore \pm circular in outline, pore diameter 2.76 $\mu \mathrm{m}(2.57-3.11 \mu \mathrm{m})$; margins well-defined; annulus slightly raised, $1.24 \mu \mathrm{m}(0.81-1.63 \mu \mathrm{m})$ wide; welldefined solid operculum. Endoaperture - pore congruent with ectoaperture, formed by a thin area of nexine.

Ornamentation: Verrucate, the verrucae large, irregular in outline, often rather diffuse, channels between verrucae with minute puncta.

Comments: The most obvious distinguishing character of the $P$. lanceolata type is the complete operculum. This type is the only one of the family that is truly operculate (Clarke, Jones lc). In the $P$. lanceolata type the operculum is structurally similar to the rest of sexine, as in $P$. alpina. Pollen grains are not distinctly microechinate (Fægri, Iversen 1992). Clarke, Jones (1997) give the following parameters of pollen grains in NW Europe: in the P plane (21) 24-32 (34) $\mu \mathrm{m}$, pore diameter 3-4 $\mu \mathrm{m}$, annulus up to 2.00 $\mu \mathrm{m}$ wide. Results of our study suggest that pollen grains have smaller pores, but Sadowska et al. (1986) reported that pore diameter ranged from 4.5 to $6.0 \mu \mathrm{m}$ and the annulus was rather narrow.

\section{Species Plantago arenaria W.K.}

Plantago arenaria type (Figs 29-32)

Pollen class: 5-8 pantoporate.

Size: medium, P - 26.44 $\mu \mathrm{m}(23.68-29.21 \mu \mathrm{m}), \mathrm{E}-23.71$ $\mu \mathrm{m}(20.52-27.24 \mu \mathrm{m})$.

P/E ratio: 1.11 (1.00-1.25): grains usually subprolate, spherical or prolate spheroidal.

Apertures: Ectoaperture - pore rather irregular to \pm circular or elliptical, sometimes slightly sunken, diameter 3.23 $\mu \mathrm{m}$ (2.37-4.24 $\mu \mathrm{m})$; margin ill-defined, irregular. Annulus absent, membrane covered with granules forming an ill-defined operculum. Endoaperture - pore congruent with ectoaperture, formed by a thin area of nexine.

Ornamentation: Verrucate, the verrucae well-defined, slightly convex, irregular in outline, variable around pores. Channels between verrucae with puncta.

Comments: Pollen grains of this species are assigned to the maritima type (Clark, Jones 1977). However, marked differences were observed in both quantitative and qualitative traits, and the two species belong to different sections (see page 320 ).

As a result of clustering by the immediate neighbourhood method with Manhattan distances, a fenogram was constructed on the basis of quantitative and qualitative traits (Fig. 33). Three groups can be seen on the dendrogram: (1) 

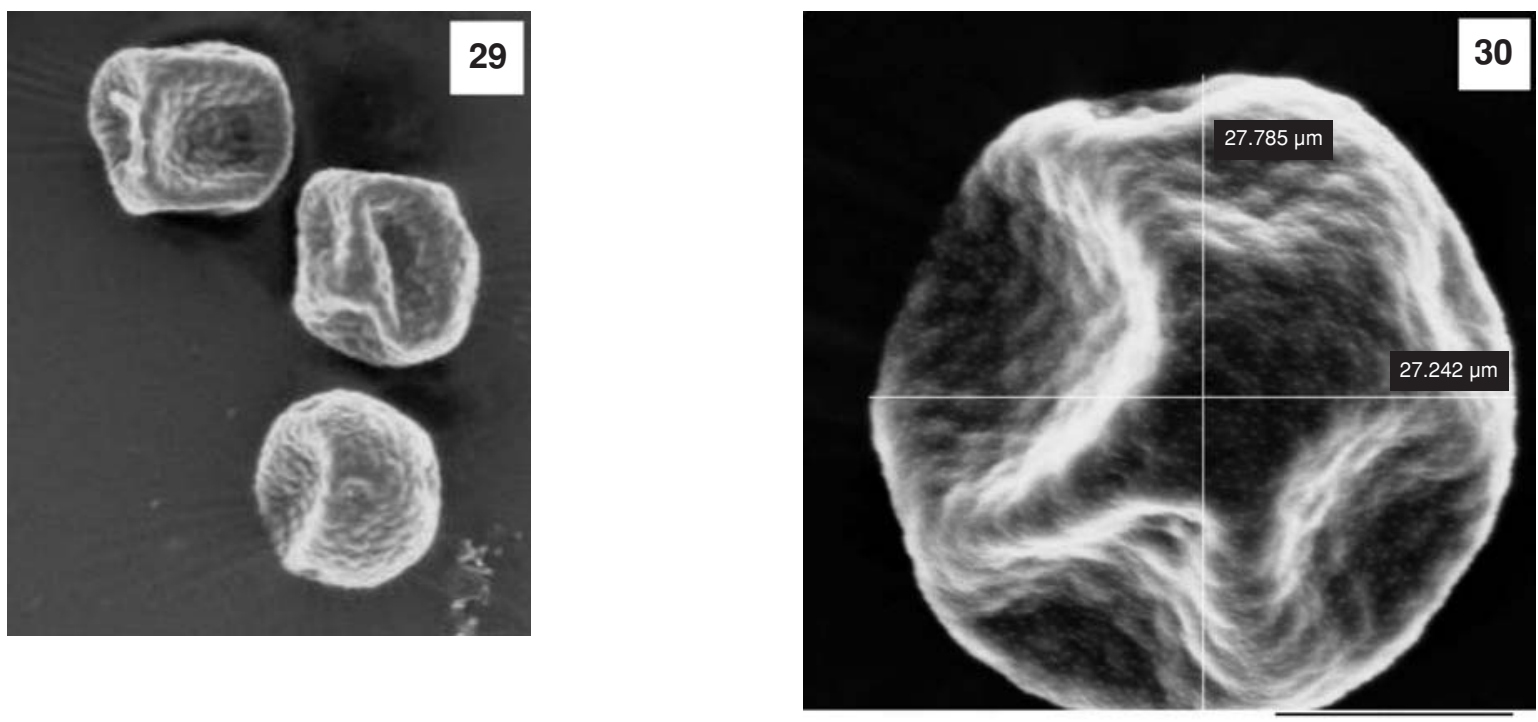

$10 \mu \mathrm{m}$
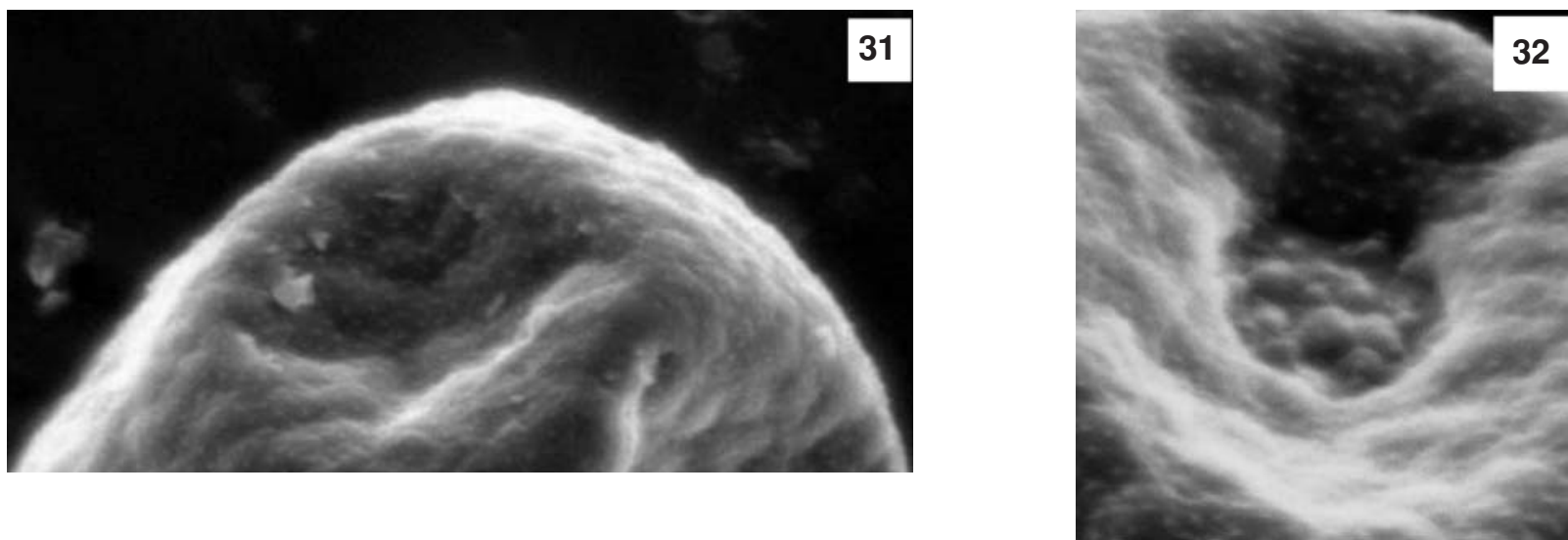

Figs 29-32 Plantago arenaria Waldst. \& Kit.

Fig. 29. Pollen grains $(\times 600)$

Fig. 30. Overall view with pores $(\times 2980)$.

Fig. 31. Ornamentation and sunken pores $(\times 2500)$

Fig. 32. Pore with granulate operculum $(\times 6200)$.

$P$. maritima subsp. maritima, $P$. intermedia, and $P$. major; (2) $P$. media, $P$. atrata subsp. carpatica, and $P$. arenaria; and (3) $P$. coronopus subsp. coronopus and $P$. alpina. The most distinct is $P$. lanceolata, which occupies an isolated position. Similarity can be noticed between some of the distinguished pollen grain types, for example between the $P$. major type and $P$. maritima type; however, $P$. arenaria assigned to the $P$. maritima type - occupies a distinct position.

\section{CONCLUSIONS}

1. The $P$. major type includes pollen grains of $P$. major and $P$. intermedia. The greatest differences concern sculpture, which is highly variable in $P$. intermedia. Pollen grains are covered with spherical, irregular, or club-shaped verrucae. In mature anthers of $P$. intermedia, pollen grains vary in size and shape, but sculpture is similar. Differences between the two species concern also pore diameter: 4.59 $\mu \mathrm{m}$ in $P$. major and 2.37 in $P$. intermedia. Hence we suggest that a separate $P$. intermedia type should be distinguished.
2. Pollen grains of the $P$. media type are verrucate. The verrucae are large, coarse; pores often sunken, with granulation.

3 . The P. coronopus type is characterized by the well-developed annulus. In our opinion this type should include also $P$. alpina, in which the annulus is partly open, consisting of two long parts.

4. Pollen grains of native species of the $P$. maritima type are distinguished by the annulus composed of disjunct verrucae around the pore. Pollen grains of $P$. maritima and $P$. arenaria, so far assigned to the maritima type, are very different from each other in terms of sculpture, aperture membrane, and location of the pore, which is deeply sunken in $P$. arenaria. Thus we suggest that $P$. arenaria should be assigned to a separate type.

5. Pollen grains of $P$. lanceolata have a complete operculum. The operculum is structurally similar to the rest of sexine, as in $P$. alpina. Besides, the annulus around the pore is continuous and wide but relatively flat.

6. Clustering by the immediate neighbourhood method, based on quantitative and qualitative traits of pollen grains of the studied species, revealed a great similarity within three groups: (1) $P$. maritima subsp. maritima, $P$. intermedia, 


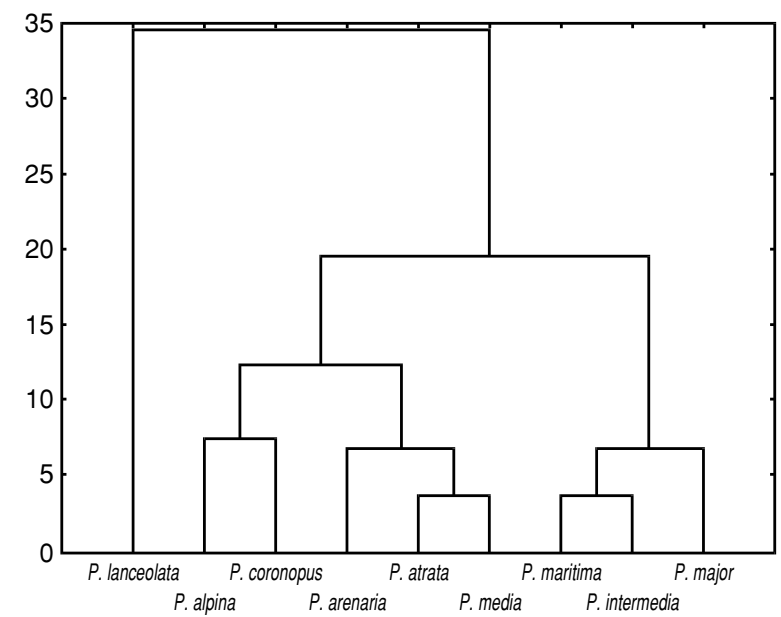

Fig. 33. Fenogram constructed on the basis of quantitative and qualitative traits of pollen grains of Plantago species.

and $P$. major, (2) P. media, P. atrata subsp. carpatica, and $P$. arenaria; and (3) $P$. coronopus subsp. coronopus and $P$. alpina. The most distinct is $P$. lanceolata.

\section{LITERATURE CITED}

BEDINGER P. 1992. The remarkable biology of pollen. The Plant Cell 4, 879-887.

CASPER J. 1975. 121. Familie Plantaginaceae, In: Hartl D. et Wagenitz G. (ed.), Hegi G., Illustrierte Flora von Mitteleuropa ed. 2, 6/1: 559-608. Verl. P. Parey, Berlin und Hamburg.

CHATER A.O., CARTIER D. 1976. Plantago. In: T.G. Tutin, V.H. Heywood, N.A. Burges, D.M. Moore, D.H. Valentine and S.M. Walters (ed.), Flora Europaea, 4 Cambridge Universitety Press, Cambridge, pp. 38-44.

CLARKE G.C.S., JONES M.R. 1977. Plantaginaceae. In: The North west European Pollen Flora. Rev. Paleobot. Palynol. 24 (4): 129-154

CZAPSKA D. 1959. Badania cytologiczno-morfologiczne nad Plantago media L. i innymi gatunkami rodzaju Plantago. (Cytological and morphological studies in Plantago media L. and other species of the genus Plantago). Acta Soc. Bot. Pol., Warszawa, 28/1: 129-142.

DIETRYCH H. 1968. Pollenbestimmungsschlüssel mitteleuropaischer Plantaginaceae. Wiss. Z. Friedrich-Schiller-Uniw., Jena, Math.-Naturwiss. Reihe, 3: 359-361.

ERDTMAN G. 1952. Pollen morphology and plant taxonomy. Angiosperms. An introduction to palynology 1. Almquist and Wiksell. Stockholm.

FÆGRI K., IVERSEN J. 1975. Textbook of Pollen Analysis Munksgoard, Copenhagen 3 rd ed., 295 pp.

FÆGRI K., IVERSEN J. 1992. Textbook of pollen analysis. John Wiley \& Sons Chichester, New York, Brisbane, Toronto, Singapore, p. 286.

HESLOP-HARRISON J. 1971. The pollen wall: Structure and development. In: Pollen Development and Physiology. Heslop-Harrison (ed.), Butterworth, London, pp. 75-98.
HESLOP-HARRISON J. 1972. Patterns in plant cell walls: Morphogenesis in miniature. Proceedings of Royal Institute, Great Britain 45, 75-98.

IVERSEN J. 1941. Land occupation in Denmark's Stone Age. A pollennalytical study of the inflience of farmer culture on the vegetational development. Dankmalis Geob. Unders., R II Nr 66.

KLIMKO M., KLUZA M., KREFT A. 2000. Morphology of pollen grains in three varieties of Helianthus annuus L. Rocz. Akad. Rol. w Pozn. s. Botanika 3: 135-142.

KLIMKO M., IDZIKOWSKA K., TRUCHAN M., KREFT A. 2004. Seed sculpture of Polish species of the genus Plantago L. Acta Soc. Bot. Pol. 73 (2): 103-111.

MCCORMIC S. 1993. Male gametophyte development. The Plant Cell 5, 1265-1275.

MIREK Z., PIĘKOŚ-MIRKOWA H., ZAJĄC A., ZAJĄC M. 1995. Krytyczna lista roślin naczyniowych Polski. A Check list [Vascular plants of Poland]. Pol. Bot. Stud. Guideb. Ser. 15.

MOORE P.D., WEBB J.A., COLLINSON M.E. 1991. Pollen analysis. Blackwell Scientific Publications. London, Edinburgh, Boston.

MÜLLER I. 1947. Die pollenanalytische Nachweis der menschlichen Besiedlung im Federsee und Bodenseegebiet. Planta, Bd 35, II. 112.

NEPI M., CIAMPOLINI F., PACINI E. 1995. Development of Cucurbita pepo pollen: ultrastructure and histochemistry of the sporoderm. Canadian J. Bot. 73: 1046-1057.

OTTAVIANO E., MULCAHY D.L. 1989. Genetics of angiosperm pollen. Advances in Genetics 26: 1-64.

PIĘKOŚ-MIRKOWA H. 2001. Plantago atrata Hoppe. In: Polish red date Book of plants. Polish Acad. of Scien. W. Szafer Institute of Botany, Inst. of Nat. Conserv. In: Kaźmierczakowa R., Zarzycki K. (ed.).

PIOTROWSKA H. 2001a. Plantago coronopus L. In: Polish red date Book of plants. Polish Acad. of Scien. W. Szafer Institute of Botany, Inst. of Nat. Conserv. In: Kaźmierczakowa R., Zarzycki K. (ed.).

PIOTROWSKA H. 2001b. Plantago maritima L. In: Polish red data book of plants. Polish Acad. of Scien. W. Szafer Institute of Botany, Inst. of Nat. Conserv. In: Kaźmierczakowa R., Zarzycki K. (ed.).

Polish red date Book of plants. 2001. Polish Acad. of Scien. W. Szafer Institute of Botany, Inst. of Nat. Conserv. In: Kaźmierczakowa R., Zarzycki K. (ed.) Cracow.

RUTKOWSKI L. 1998. Klucz do oznaczania roślin naczyniowych Polski niżowej, PWN, Warszawa.

SADOWSKA A., KUSZELL T., LORENC K. 1986. Plantago lanceolata L. In: Kartoteka palinologiczna roślin polskich. Zeszyty Przyrod. Opol. Tow. Przyj. Nauk 24: tab. 294.

STACHURSKA A., SADOWSKA A., KUSZELL T. 1981. Plantago montana. In: Kartoteka palinologiczna roślin polskich. Zeszyty Przyrod Opol. Tow. Przyj. Nauk. 2: tabl. 294.

STANLEY R.G., LINSKENS H.F. 1985. Aminosäuren und Proteine. In: Stanley R.G., Linskens H.F. (eds). Pollen Biologie Biochemie, Gewinnung und Verwendung, Freund, Greifenberg. pp. 12-23.

StatSoft Inc. 2002. Statistica for Windows [User's manual], Tulsa.

TACIK T. 1967. Rodzina Plantaginaceae - Babkowate. In: Flora Polska. Rośliny naczyniowe Polski i ziem ościennych. B. Pawłowski (ed.). PWN, Warszawa-Kraków, 11: 238-256. 